\title{
Economic Potential of the Regions of the Czech Republic
}

\author{
P. Tuleja and K. Gajdová
}

\begin{abstract}
Aim of this paper is to evaluate the economic potential of the fourteen regions of the Czech Republic and based on this assessment to describe the degree of regional disparities in the Czech Republic. In addition there is the description of the economic potential of the region. In the second part of the paper there is analysis of the development of the selected indicators and the assessment of regional disparities. There is the evolution of five selected indicators and there is the description of differences of this evolution. Subsequently, during to use these indicators there is calculated average values and these are compared with the optimal values. It is by using graphical methods of magic polygons. Based on the analysis we concluded that the region which best uses its economic potential is Prague. This region has long been placed on the top of our imaginary scale in both in the assessment of individual indicators and in the total score. The contrary, the worst results are in Karlovy Vary Region, Moravian-Silesian Region and Usti Region.
\end{abstract}

Index Terms-Economic potential, regional disparities, magic polygon, Czech Republic.

\section{INTRODUCTION}

The professional and lay public is faced with problems in the assessment of differences in the development of territorial units. As we are aware this problem we decided to also contribute by our own view on the issue. We analyze the development of regional disparities in the economic potential of regions. We use available statistical data. We are focused on regions of the Czech Republic (NUTS3). In the end, then we will focus on graphical representation of differences, though using the magic pentagon.

\section{LITERATURE REVIEW}

Kutscherauer et al. [1] define the regional disparities as differences or inequality of characters or processes which have a definite territorial location and which are occur at least in two entities of territorial structures. We can say that the regional disparities can be seen as a phenomenon and its identification and the assessment is important only if there is view from multiple disciplines. However, this approach has one major problem. It is the need to clearly identify the contents and the range of the regional differences. For this step there are used different techniques which have both quantitative and qualitative character. Based on the analysis

Manuscript received September 10, 2013; revised November 11, 2013. This research was financially supported by the Student Grant Competition SU within the project SGS/7/2012 "The influence of regional disparities on the business environment".

P. Tuleja and K. Gajdová are with the Department of Economics, School of Business Administration, Silesian University, 73340 Czech Republic (e-mail: gajdova@opf.slu.cz, tuleja@opf.slu.cz). there are selected specific indicators which evaluate the potential regional differences. [2] The same approach to the assessment of regional disparities is chosen by authors of this paper. Given the range of the article we can't present our comprehensive view. We are focused in this section of the text to the area of economic potential of the region. [3]

Among the indicators of the economic potential of the region we have included five of indicator [4], these are (1) the regional gross domestic product per inhabitant, (2) net available income of household per inhabitant, (3) gross fixed capital per inhabitant, (4) unemployment rate and (5) amount of compensation of employees.

\section{QUANTIFICATION OF INDICATORS THAT CAPTURE THE ECONOMIC POTENTIAL OF THE REGION}

The first indicator is the gross domestic product per inhabitant. It represents the monetary value of total final production which was made in the region in the specific time period per inhabitant.

\begin{tabular}{lcccccc}
\multicolumn{6}{c}{ TABLE I: THE GROSS DOMESTIC PRODUCTS PER INHABITANT } \\
\hline \hline Region & 2001 & 2003 & 2005 & 2007 & 2009 & 2011 \\
\hline Czech Republic & $\mathbf{2 3 9 4 8 7}$ & $\mathbf{2 6 3 4 9 7}$ & $\mathbf{3 0 4 4 7 8}$ & $\mathbf{3 5 4 8 0 8}$ & $\mathbf{3 5 8 2 8 8}$ & $\mathbf{3 6 4 2 4 9}$ \\
Prague & 485777 & 552425 & 639470 & 759758 & 763959 & 768173 \\
Central Bohemia & 225171 & 246087 & 277088 & 330739 & 321140 & 325797 \\
South Bohemia & 218392 & 238535 & 275950 & 307045 & 307377 & 306576 \\
Plzeň & 223156 & 248697 & 288451 & 328653 & 310043 & 326513 \\
Karlovy Vary & 200404 & 218868 & 237537 & 262925 & 265793 & 260083 \\
Ústí & 193880 & 220158 & 250381 & 285765 & 300399 & 289851 \\
Liberec & 213143 & 212476 & 252791 & 274191 & 267708 & 279733 \\
Hradec Králové & 222603 & 234508 & 264873 & 301849 & 311307 & 315307 \\
Pardubice & 203456 & 221812 & 249765 & 297475 & 290687 & 297755 \\
Vysočina & 206220 & 221832 & 254853 & 297835 & 294647 & 303263 \\
South Moravia & 221410 & 244303 & 274819 & 325239 & 338928 & 341024 \\
Olomouc & 187090 & 203507 & 229065 & 262406 & 270526 & 281540 \\
Zlín & 200205 & 216570 & 245280 & 288497 & 307993 & 308642 \\
Moravia-Silesia & 187524 & 203774 & 258615 & 297281 & 294621 & 317835 \\
\hline \hline
\end{tabular}

In the case of GDP per inhabitant we can the individual regions of the Czech Republic split into three quality zones.

In the first zone there are all of regions in which the value of the indicator is over 300 thousand CZK in the long time. In this group there is only Region of Capital City of Prague (short only Prague), where the average gross domestic product per inhabitant was 553.959 thousand CZK. It is twice of excess of national average. [5]

The second zone is consists the South Moravian Region, Plzen Region, Central Bohemia Region, South Bohemia Region, Hradec Kralove Region, Pardubice Region, Zlin Region, Usti Region, Moravian-Silesian Region, Region 
Vysocina and Liberec Region.

The last zone is characterized by the lowest long-term standard of living. In this zone there is Karlovy Vary Region and Olomouc Region. The significant decline is in Karlovy Vary Region. It is region with the largest problems in the standard of living of the population.

This analysis is in Table I. These values are in CZK. There is analyzed the period 1995-2011, but in table, there is showed only the period 2001-2011 (only odd years).

Other indicator which we proposed for the assessment of the economic potential of region is the net available income of household per inhabitant. It shows the total amount of money. The households can use this money for the purchase of goods and services which are for to satisfy their individual needs. Or they can save it in the form of pensions which can then be used for the purchase of financial and non-financial assets or for to repay. It shows Table II:

TABLE II: THE NET AVAILABLE INCOME OF HOUSEHOLD PER INHABITANT

\begin{tabular}{lcccccc}
\hline \hline Region & 2001 & 2003 & 2005 & 2007 & 2009 & 2011 \\
\hline Czech Republic & $\mathbf{1 2 7 6 3 2}$ & $\mathbf{1 3 8 4 4 2}$ & $\mathbf{1 5 3 8 3 4}$ & $\mathbf{1 7 4 3 6 0}$ & $\mathbf{1 9 0 4 3 7}$ & $\mathbf{1 9 0 3 8 9}$ \\
Prague & 168441 & 188162 & 204004 & 230578 & 244408 & 250121 \\
Central Bohemia & 131887 & 149701 & 164264 & 187150 & 205028 & 206669 \\
South Bohemia & 123222 & 134401 & 148869 & 168100 & 183022 & 181215 \\
Plzeň & 128746 & 137298 & 153548 & 172868 & 186959 & 187924 \\
Karlovy Vary & 122063 & 130535 & 140396 & 156050 & 172411 & 171785 \\
Ústí & 117291 & 124125 & 136523 & 152960 & 171272 & 170925 \\
Liberec & 124268 & 131640 & 145709 & 162996 & 177985 & 178750 \\
Hradec Králové & 128194 & 133919 & 150288 & 168919 & 187499 & 179715 \\
Pardubice & 117486 & 127543 & 146826 & 165325 & 180680 & 177064 \\
Vysočina & 116024 & 128892 & 144331 & 165652 & 180818 & 180102 \\
South Moravia & 125244 & 132893 & 150727 & 171168 & 187503 & 184823 \\
Olomouc & 118051 & 128043 & 139681 & 160623 & 175568 & 172415 \\
Zlín & 120938 & 130605 & 144962 & 168523 & 178621 & 178580 \\
Moravia-Silesia & 115894 & 122680 & 139628 & 157100 & 174505 & 176135 \\
\hline \hline
\end{tabular}

Like in the previous case also with this indicator there is the first zone formed by Region Prague. Now we can assign also the Central Bohemia Region. So here the value exceeded one hundred percent of average value of net available income in the Czech Republic. In addition there was also an extension of third zone where there is the Karlovy Vary Region and Olomouc Region and also Zlin Region, Pardubice Region, Vysocina Region, Moravian-Silesian Region and Usti Region. These are regions which in the long term perspective are below 95 percent of average value of net available income in the Czech Republic. The region in this area which is the worst score we can mark the Usti Region. There is the average value of real indicator is lower about ten percentage points than the average of the Czech Republic.

Also in the case of this indicator we can say the highest values are in Region Prague where the average value of this indicator was at about $129.66 \%$ of the national average.

The contrary Usti Region and Karlovy Vary region are regions with the worst results. The share of this indicator on the national average is decreasing. It suggests divergence process by which these regions through. Their share of the national average decreased from the 97.06 and the 97.48 percentage to the 89.78 and 90.23 percent.
The third of the indicators is an indicator of gross fixed capital per inhabitant which shows the value of tangible and intangible fixed assets and net acquisitions of non-produced non-financial assets, which economic subjects to obtain purchase, transfer without consideration or production for own account. All of this is calculated per inhabitant of the region. This indicator means is an expression of the investment potential of the region. It shows Table III:

TABLE III: THE GROSS FIXED CAPITAL PER INHABITANT

\begin{tabular}{lrrrrrr}
\hline \hline Region & 2001 & \multicolumn{1}{c}{2003} & 2005 & 2007 & 2009 & 2011 \\
\hline Czech Republic & $\mathbf{6 7 9 8 3}$ & $\mathbf{7 0 6 4 1}$ & $\mathbf{7 8 6 1 9}$ & $\mathbf{9 5 8 6 7}$ & $\mathbf{8 8 2 7 0}$ & $\mathbf{8 7 8 9 7}$ \\
Prague & 152770 & 154020 & 183267 & 267932 & 227035 & 214496 \\
Central Bohemia & 64900 & 67195 & 82639 & 79332 & 65544 & 79132 \\
South Bohemia & 71332 & 69827 & 76469 & 66577 & 73460 & 67015 \\
Plzeň & 55594 & 60341 & 62134 & 93182 & 96541 & 69020 \\
Karlovy Vary & 62962 & 68375 & 66369 & 61899 & 62177 & 74111 \\
Ústí & 64028 & 68101 & 56620 & 86112 & 84236 & 96928 \\
Liberec & 43841 & 63320 & 56439 & 56168 & 52761 & 58889 \\
Hradec Králové & 43458 & 52564 & 48438 & 53444 & 58010 & 50356 \\
Pardubice & 52153 & 48474 & 48778 & 63503 & 54894 & 61984 \\
Vysočina & 52614 & 50907 & 65075 & 73810 & 64281 & 63121 \\
South Moravia & 53769 & 78924 & 92268 & 94007 & 80235 & 79499 \\
Olomouc & 67877 & 48696 & 53451 & 62290 & 76556 & 61210 \\
Zlín & 50764 & 50779 & 47658 & 58664 & 50039 & 55535 \\
Moravia-Silesia & 52527 & 44374 & 55864 & 68684 & 66736 & 72225 \\
\hline \hline
\end{tabular}

In the case of the first zone of regions we reach the same conclusion as the gross domestic product per inhabitant. Also in this case, the first zone of regions is formed by only Region Prague. There the average value of the indicator analyzed exceeded one hundred percent of the value of the national average $(226.71 \%)$.

The second zone of regions is consists of Plzen Region, South Moravia Region, South Bohemia Region, Usti Region, Central Bohemia Region, Karlovy Vary Region and Moravia-Silesian Region In the Moravian-Silesian Region there the share of The gross fixed capital per inhabitant on the national average significantly closer to the $75 \%$.

The last zone where we belong to the regions with the gross fixed capital per inhabitant was below three quarters of the national average. There is Vysocina Region, Pardubice Region, Liberec Region, Hradec Kralove Region and Zlin Region.

General unemployment rate is the fourth indicator of economic potential. It expresses the \% proportion of the unemployed (who are detected based on the Labour Force Survey) in the total economically active population. We can mark it as an indicator, which inherently expresses unmet offer of the labor.

If we use again the classification into three separate zones we find the following. In the first zone, highest rated, we capture all of the regions for which the unemployment rate will be below five percent. This group includes Region Prague, South Bohemia Region, Central Bohemia Region and Plzen Region. The average general unemployment rate amounted to $4.98 \%$. The first group consists of such regions for which the unemployment rate exceeded $75 \%$ of the 
national average.

The second zone consists of Hradec Kralove Region, Vysocina Region, Pardubice Region, Liberec Region and South Moravian Region. The South Moravian Region is also the last region where the average general rate of unemployment does not reach an average of national.

The last zone is characterized by the largest proportion of long-term unemployed in the total number of economically active population in the region. It is composed of the Zlín Region, Karlovy Vary Region, Olomouc Region, Moravian-Silesian Region and Ústí Region. In these regions there is the average value of the indicator above the national average, which was exceeded by at least 1.16 percentage points in the case of Zlin Region and by a maximum of 78.01 percentage points in the case of the Ústí Region. Usti Region we can consider the region with the largest problems in the unemployment rate. It shows Table IV. [6]

TABLE IV: THE UNEMPLOYMENT RATE (\%)

\begin{tabular}{lrrrrrr}
\hline \hline Region & \multicolumn{1}{c}{2001} & \multicolumn{1}{c}{2003} & \multicolumn{1}{c}{2005} & 2007 & 2009 & 2011 \\
\hline Czech Republic & $\mathbf{8 . 1 3}$ & $\mathbf{7 . 7 8}$ & $\mathbf{7 . 9 3}$ & $\mathbf{5 . 3 2}$ & $\mathbf{6 . 6 6}$ & $\mathbf{6 . 7 1}$ \\
Prague & 3.86 & 4.19 & 3.51 & 2.44 & 3.06 & 3.60 \\
Central Bohemia & 6.73 & 5.16 & 5.22 & 3.38 & 4.42 & 5.08 \\
South Bohemia & 5.60 & 5.17 & 5.02 & 3.29 & 4.28 & 5.52 \\
Plzeň & 5.78 & 5.31 & 5.08 & 3.68 & 6.29 & 5.15 \\
Karlovy Vary & 7.37 & 6.39 & 10.91 & 8.24 & 10.91 & 8.52 \\
Ústí & 13.32 & 13.00 & 14.53 & 9.95 & 10.07 & 9.85 \\
Liberec & 6.21 & 6.11 & 6.48 & 6.05 & 7.83 & 7.22 \\
Hradec Králové & 6.10 & 5.85 & 4.77 & 4.16 & 7.70 & 7.10 \\
Pardubice & 6.37 & 7.60 & 5.64 & 4.44 & 6.43 & 5.57 \\
Vysočina & 6.08 & 5.32 & 6.77 & 4.65 & 5.67 & 6.45 \\
South Moravia & 8.55 & 8.05 & 8.09 & 5.43 & 6.83 & 7.50 \\
Olomouc & 10.41 & 9.57 & 9.99 & 6.35 & 7.64 & 7.58 \\
Zlín & 8.50 & 7.53 & 9.44 & 5.53 & 7.28 & 7.64 \\
Moravia-Silesia & 14.29 & 14.75 & 13.89 & 8.49 & 9.68 & 9.31 \\
\hline \hline
\end{tabular}

TABLE V: THE AMOUNT OF COMPENSATION OF EMPLOYEE (MONTHLY AVERAGE)

\begin{tabular}{lllllll}
\hline \hline Region & 2001 & 2003 & 2005 & 2007 & 2009 & 2011 \\
\hline Czech Republic & $\mathbf{2 0 2 1 5}$ & $\mathbf{2 3 5 0 5}$ & $\mathbf{2 6 3 8 7}$ & $\mathbf{2 9 7 3 3}$ & $\mathbf{3 0 7 8 4}$ & $\mathbf{3 2 4 9 2}$ \\
Prague & 29900 & 34507 & 39533 & 45273 & 45740 & 49842 \\
Central Bohemia & 18772 & 22499 & 25438 & 26751 & 27278 & 29618 \\
South Bohemia & 18340 & 21536 & 23751 & 25705 & 26093 & 27645 \\
Plzeň & 19181 & 21885 & 24390 & 27066 & 28213 & 29797 \\
Karlovy Vary & 16011 & 18185 & 19455 & 22543 & 24182 & 23931 \\
Ústí & 18210 & 20991 & 23411 & 26118 & 26658 & 26977 \\
Liberec & 17781 & 20739 & 23163 & 33373 & 26843 & 28160 \\
Hradec Králové & 18179 & 22097 & 23748 & 26648 & 30169 & 29449 \\
Pardubice & 17785 & 20878 & 22307 & 25578 & 26243 & 27201 \\
Vysočina & 18437 & 21029 & 23519 & 24831 & 25375 & 28095 \\
South Moravia & 18623 & 22506 & 25226 & 28696 & 31292 & 32386 \\
Olomouc & 17954 & 19826 & 22873 & 24881 & 26056 & 28509 \\
Zlín & 17695 & 19741 & 22854 & 24355 & 26257 & 27158 \\
Moravia-Silesia & 19623 & 22229 & 24286 & 27631 & 29047 & 30093 \\
\hline \hline
\end{tabular}

The last of the indicators showing economic potential of the region is the compensation of employees for one month. This indicator shows the income of households resulting from dependent work and which includes wages and salaries and employers' social contributions in the course of one month. It shows Table V.

Also here we have one region, which far exceeds all of other regions of the Czech Republic. [7] This region is again Region Prague, whose share of the national average amounts to $146.83 \%$. It means it is also the only one region that is above the average of national.

Also in the third worst rated zone, in this case there is only one region (it is the Karlovy Vary Region), in where the average monthly value of this indicator stood at CZK 18,126. It is equivalent to about 78 percent of the national average. We can describe this region like region that has long characterized the lowest employee compensation. The remaining twelve regions are in the second zone. In their case the percentage amount ranges from 86.43 to $96.54 \%$.

\section{THE ASSESSMENT OF THE DEVELOPMENT OF THE REGIONAL DisPaRITIES OF THE REGIONS OF THE CZECH REPUBLIC}

To assessment of the economic potential of the region we prefer magic polygons, where the number of vertices with the same number of indicators used for the description of the economic potential of the region. [8] We have defined the economic potential of the country by five key indicators. The individual peaks of magic polygon are shown on the axes to form a five-pointed star. Thus created magic polygon takes the form of a pentagon. The rate of economic potential is then expressed as the ratio of the area expressing the real level indicators describing the economic potential of the optimal area - equilateral pentagon.[9] For our analysis we need for optimal considered average for the entire period, so that the top of our pentagon consists of the following values: the growth rate of gross domestic product per inhabitant of $5.33 \%$ (peak g), the growth rate of net available household income per inhabitant $5.37 \%$ (peak d), the growth rate of gross fixed capital $3.26 \%$ (peak f), the general unemployment rate of $6.63 \%$ (peak u) and growth in compensation of employees $6.29 \%$ (peak w). These values were compared with the average value of the parameters of each region for the period 1995-2011 as a whole (see Fig. 1 and Fig. 2).

Comparing the magic pentagons captured in Fig. 1 and Fig. 2 , then we conclude that the only region that substantially exceeds the optimum value and the actual surface area of pentagons significantly exceeds the optimal pentagons is Region Prague. This conclusion is not surprising given and it was expected. [10] The best results are reached in indicators of gross fixed capital formation per inhabitant. The growth rate exceeded the national average by 4.22 percentage points. Other the best results are reached in indicators of the general unemployment rate, which has been compared to national average of 340 percentage points lower. Another region that exceeded optimal values is Central Bohemia Region. Regions with good economic potential we include there Region Vysocina and South Moravian Region. In the Region Vysocina there is slightly problematic development of labor costs. The long-term average growth rate lags behind the 
national average by 0.29 percentage points. In the South Moravian Region is this "critical" point of net available income of households, whose growth rate is 0.01 percentage points lower than the national average.

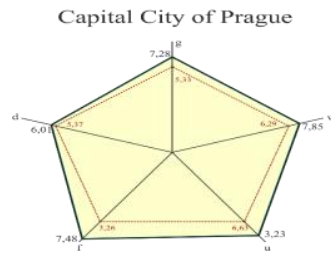

South Bohemia Region

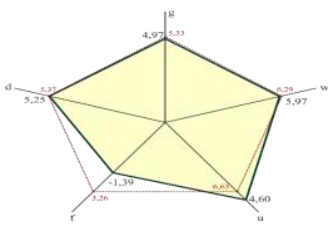

Karlovy Vary Region
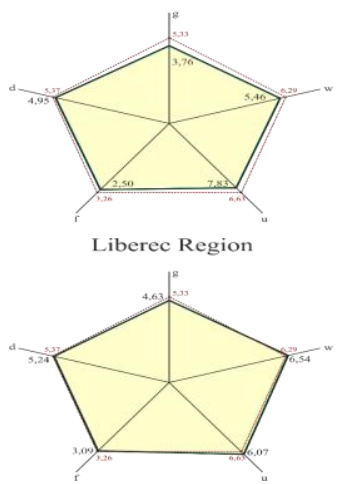

Fig. 1. The Magic pentagons of each regions of the Czech Republic (The average from period 1995-2011).
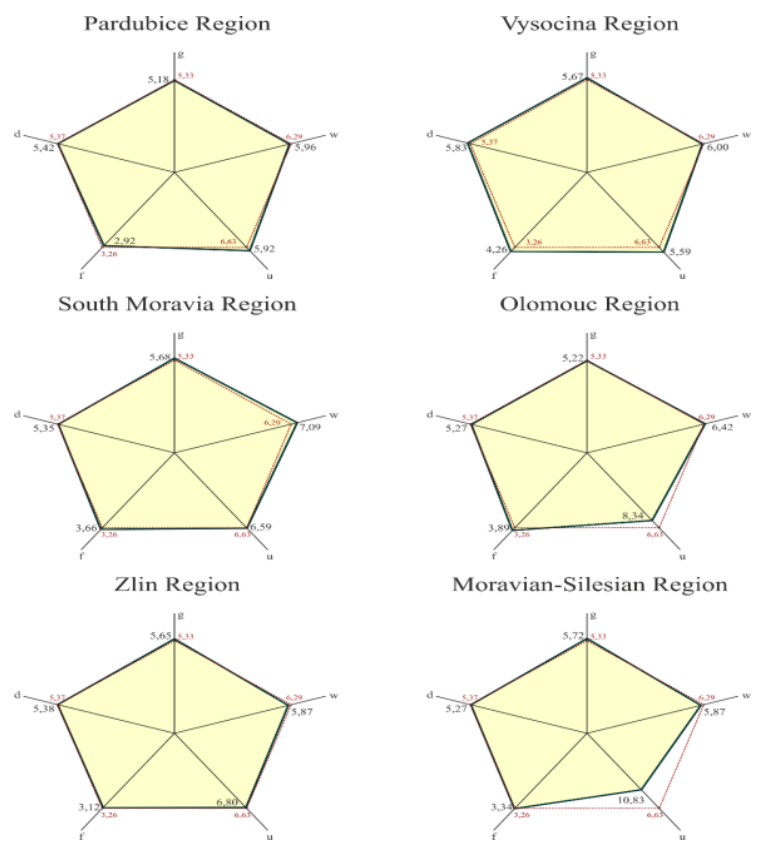

Moravian-Silesian Region

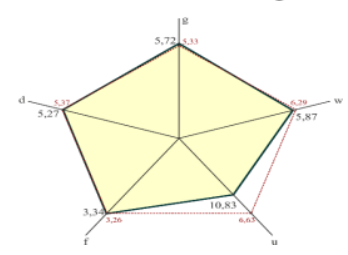

Fig. 2. The Magic pentagons of each regions of the Czech Republic (The average from period 1995-2011) - continue.

Among the regions that have the use of its economic potential long-term problems, then we classify particular region South Bohemia, Moravian-Silesian Region, Karlovy
Vary Region and Usti Region. For the most critical could be called development of the Karlovy Vary Region. It is region of all which has the peaks of his magic pentagon below the peaks of optimal pentagon.

In the case of Usti Region and the Moravian-Silesian Region we can identify particularly critical as the labor market situation. [11] In the Usti Region there the unemployment rate exceeds the national average by 5.11 percentage points. In the Moravian-Silesian Region it is by 4.20 percentage points.

The last region, which has long-term problems in the use of its economic potential, is South Bohemia Region. It is the only one which has a negative growth rate of gross fixed capital per inhabitant. This indicator reached in the region value $-1.39 \%$ and the optimum is the value of 4.03 percent.

In the remaining six regions then the real magic pentagon shape corresponds to the optimum magical pentagon.

\section{CONCLUSION}

The aim of this study was to evaluate the economic potential of the fourteen regions of the Czech Republic and on the basis of this assessment to describe the degree of regional disparities in the country. In line with this aim, we are so in the introductory part of the paper focused on the short description of the economic potential of the region. This description was as general characteristics and a list of supporting indicators through which we can determine this potential.

The analysis is in the second part of this paper. In the first we reviewed the development of five selected indicators and described differences in this development. Then we by using these indicators calculated the average values and compared with the optimal values and we used graphical methods magical polygons.

We conclude that the region that best uses its economic potential in the long term is Region Prague. On the contrary, the worst results are in the Karlovy Vary Region, Moravia-Silesian Region and Usti Region.

\section{REFERENCES}

[1] A. Kutscherauer et al., Regional Disparities: Disparities in Country Regional Development - Concept, Theory, Identification and Assessment, 1st ed. Ostrava. Czech Republic: VŠB-TUO. 2010.

[2] I. Majerova, "International development cooperation of the Czech Republic in the context of European development," Prague Economic Papers, vol. 21. pp. 166-185, June 2012.

[3] R. J. Stimson, R. R. Stough, and B. H. Roberts, Regional Economic Development: Analysis and Planning Strategy, Revised edition, 2006. Berlin: Springer.

[4] M. Tvrdoň and T. Verner, "Examining the relationship between economic performance and unemployment: The case of visegrad countries," in Proc. 29th International Conference on Mathematical Methods in Economics 2011, Jánska Dolina: University of Economics, 2011. pp. 733-738.

[5] Czech Statistical Office. (July 2013). Database of Regional Accounts [Online]. Available: http://apl.czso.cz/pll/rocenka/rocenka.indexnu_reg?mylang=EN

[6] Czech Statistical Office. (July 2013). Employment. Unemployment. [Online]. Available: http://www.czso.cz/eng/redakce.nsf/i/employment_unemployment_ek on

[7] K. Fojtíková and P. Tuleja, "Demographic progression of the Moravian-Silesian region." in Proc. 10th International Scientific 
Conference Economic Policy in the European Union Member Countries, Karviná: Silesian University, 2013, pp. 66-76.

[8] M. Tvrdoň, "Institucionální aspekty fungování trhu práce," Politická ekonomie, LVI (5), pp. 621-642, 2008.

[9] R. Stimson, R. R. Stough, and P. Nijkamp, Endogenous Regional Development: Perspectives, Measurement and Empirical Investigation, Cheltenham: Edward Elgar, 2011, 337.

[10] K. Skokan, Evropská Regionální Politika: V Kontextu Vstupu České Republiky do Evropské Unie. 1. Vyd, Ostrava: Repronis, 2003. 114.

[11] K. Gajdová and P. Tuleja, "Regional disparities in the european union: focused on the wages and their development," in Proc. 3rd International Conference on Economics, Trade and Development in Bangkok, Thailand, Hong Kong: IEDR, 2013, pp. 262-266.

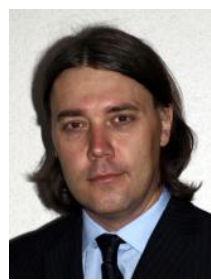

P. Tuleja was born in Ostrava in the Czech Republic on the $31^{\text {st }}$ of March 1971. He studied at the VŠB-Technical University of Ostrava. In 2008 he graduated successfully habilitation and he is associate professor and now he prepares for getting the title Prof. Immediately after the study began working at the Silesian University in Opava. School of Business Administration in Karvina. Department of economics. Since 2010 he is head of department of economics. And since January 2013 he is the dean of the School of Business
Administration in Karvina.

$\mathrm{He}$ is respected expert in the field of economic. Policy and governance. Moreover he works in other public institutions. For example he is member of Committee of the Social Council of Moravian-Silesian Region. A member of the Expert Group for Strategy of Development of Moravian-Silesian Region and so on.

Whereas he works at the Silesian University he authored more than 180 publications in the field of economics, economy policy. etc.

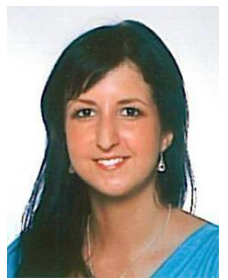

K. Gajdová was born in Ostrava in the Czech Republic on the $21^{\text {st }}$ of June 1986. She studied business academy in Ostrava and then she studied at the Silesian University in Opava. School of Business Administration in Karvina. Now she studies for Ph.D. whereas she is employed as academic staff at the Silesian University. She also works for the Regional Development Agency. it is an institution dedicated to the development of Moravian-Silesian Region. She deals with the regional disparities and national economies. She has published many articles during her studies and work. for example: "Unemployment in the European Union context with selected indicators in 2010". "Changes in selected characteristics of the EU labour market in times of economic crisis" - these papers were presented at a conference in Barcelona. Spain and these papers are in database Web of Science. 